\title{
HISTOCHEMICAL ASPECTS OF RESERVES MOBILIZATION OF Caesalpinia peltophoroides (LEGUMINOSAE) SEEDS DURING GERMINATION AND SEEDLINGS EARLY GROWTH ${ }^{1}$
}

\author{
Viviana Borges Corte ${ }^{2}$, Eduardo Euclydes de Lima e Borges ${ }^{3}$, Marília Contin Ventrella ${ }^{4}$, Idalina Tereza de
} Almeida Leite ${ }^{5}$ e Antônio Jorge Tourinho Braga ${ }^{2}$

\begin{abstract}
The objective of this study was to investigate reserve mobilization in Caesalpinia peltophoroides seeds during germination and initial seedling growth. The variation in these compounds was analyzed from the pre-germination period ( 0 to 5 days after sowing - DAS) to the total cotyledon senescence and abscission at 35 DAS. For this histochemical tests were made on cotyledons fixed in FAA50 or included in glycol-metacrylate. To follow the mobilization of the main reserve compounds, sudan III was used to detect total lipids, xylidine Ponceau to detect total proteins, lugol to detect starch and polarized light to visualize the crystals. The lipids, present in a great quantity in the cotyledon, gradually decreased in the period studied. A greater quantity of starch was observed on the 10th DAS than in the previous periods and it was totally consumed by 30 DAS. The distribution pattern and the morphology of the protein material were very modified by 10 DAS, a period during which it was intensely consumed, remaining only parietally fragments distributed, that practically disappeared at 25 DAS. The calcium oxalate druses were not consumed during the period studied, there was only crystal agglutination.
\end{abstract}

Keywords: Reserve materials, carbohydrates, lipids, proteins and calcium oxalate.

\section{ESTUDO HISTOQUÍMICO DA MOBILIZAÇÃO DE RESERVAS DE SEMENTES DE Caesalpinia peltophoroides (LEGUMINOSAE) DURANTE A GERMINAÇÃO E CRESCIMENTO INICIAL}

\begin{abstract}
RESUMO - Este trabalho teve como objetivo o estudo da mobilização de reservas de sementes de Caesalpinia peltophoroides Benth. durante a germinação e crescimento inicial das plântulas. As variações nesses compostos foram analisadas desde o período pré-germinativo ( 0 a 5 dias após a semeadura - DAS) até a total senescência e abscisão dos cotilédones, aos 35 DAS. Para isso, foram realizados testes histoquímicos em cotilédones fixados em FAA50 ou incluídos em glicol-metacrilato. Para acompanhamento da mobilização dos principais compostos de reserva, foi usado o sudan III para deteç̧ão de lipídios totais, xylidine Ponceau para proteínas totais, Lugol para amido e luz polarizada para visualização dos cristais. Os lipídios, presentes em maior quantidade nos cotilédones, apresentam decréscimo gradativo no período estudado. No $10^{\circ} \mathrm{DAS}$, observouse maior quantidade de amido que nos períodos anteriores, sendo totalmente consumido até os 30 DAS. O padrão de distribuição e morfologia do material protéico modificaram-se bastante até os 10 DAS, período em que foi intensamente consumido, restando apenas fragmentos parietalmente distribuídos, que praticamente desaparecem após 25 DAS. As drusas de oxalato de cálcio não foram consumidas durante o período estudado, apenas houve aglutinação dos cristais.
\end{abstract}

Palavras-chave: Reserva material, carboidratos, lipídios, proteínas e oxalato de cálcio.

\footnotetext{
${ }^{1}$ Recebido em 11.05.2007 e aceito para publicação em 19.05.2008.

${ }^{2}$ ProgramadePós-Graduaçãoem CiênciaFlorestal daUniversidadeFederal de Viçosa(UFV), Viçosa-MG E-mail: <viviborgescorte@yahoo.com.br> .

${ }^{3}$ Departamento de Engenharia Florestal da UFV. E-mail: <elborges@ufv.br>.

${ }^{4}$ Departamento de Biologia Vegetal da UFV. E-mail: < ventrella@ufv.br>.

${ }^{5}$ Departamento de Biologia da Universidade Federal do Espírito Santo. E-mail: <idatal21@gmail.com>.
} 


\section{INTRODUCTION}

Caesalpinia peltophoroides Benth. (LeguminosaeCaesalpinoideae), popularly known as "sibipiruna” or false Brazil wood, has ornamental and timber potential. It is native to the Brazilian Atlantic rainforests, mainly in Rio de Janeiro, southern Bahia, São Paulo, Espírito Santo and in the Pantanal region in the state of Mato Grosso (LORENZI, 2002). However, its occurrence has been rare in the forests, although it is a not very demanding species regarding soil type and it produces annually a large quantity of seeds which are not commonly predated.

Germination involves anatomic or morphological, genetic, metabolic and hormonal events (BORGES and RENA, 1993) and the substrates for this rapid metabolic alteration are the reserve compounds stored in the seeds (MANSFIELD and BRIARTY, 1996). These are mobilized and used as energetic fuel for germination and post-germination growth until the seedlings are sufficiently autotrophic (DAVIES and SLACK, 1981; SILVA etal., 1998; PRITCHARD etal., 2002; BUCKERIDGE et al., 2004).

Recently, studies regarding the physiology and biochemistry of Caesalpinia peltophoroides seed germination have been carried out (BORGES et al., 2005; CORTE et al., 2006). However, physiological changes in the seeds during germination are normally accompanied by morpho-anatomic changes, and these can be detected in situ by specific histochemical techniques (SILVA et al., 1998). These structural changes related to reserve degradation in seeds have been reported (CORTELAZZO and VIDAL, 1991; STONE and GIFFORD, 1997; SILVA et al., 1998).

Thus, considering histochemistry as a relevant tool to study the morpho-anatomic changes, in the present study, these techniques were applied to Caesalpinia peltophoroides seeds aiming to characterize the process of reserve mobilization during germination and early seedling growth by comparing the anatomic and biochemical aspects.

\section{MATERIALS AND METHODS}

This study was carried out in the Forest Seed Laboratory at the Department of Forest Engineering and in the Plant Anatomy Laboratory at the Department of Plant Biology at the Federal University of Viçosa.
The Caesalpinia peltophoroides seeds used were collected from a minimum of 10 trees in the region of Viçosa, Minas Gerais (S 2045'15,4" - W 4251'14,4"') Immature, deteriorated or damaged seeds were eliminated during beneficiation. The seeds were treated in a $0.5 \%$ Captan solution and placed to germinate on a seed tray in sand previously sterilized with methyl bromide $\left(20 \mathrm{~mL} \mathrm{~m}^{-2}\right)$.

The cotyledons were collected every five days since before sowing and until the total cotyledon senescence and abscission at 35 DAS, according to Corte et al. (2006). After collection, the cotyledons were fixed in FAA50 for 48 hours and stored in 70\% ethanol (JOHANSEN, 1940). For the histochemical studies, the mid region of the cotyledon was selected, which was sectioned in a table microtome and rotating microtome with $7 \mu \mathrm{m}$ thickness, without and with inclusion medium (glycol-metacrylate - HistoresinLeica $\left.{ }^{\circledR}\right)$, respectively, following recommendations by Carmello-Guerreiro (1995). The cuts obtained from fixed material (without inclusion medium) were submitted to histochemical tests with sudan III to identify total lipid (JOHANSEN, 1940) and xylidine Ponceau (XP) to identify total proteins (VIDAL, 1977), besides mounted on glycerine gelatine and submitted to the tests with acetic acid and nitric acid to verify the chemical nature of the crystals (CHAMBERLAIN, 1932). The cuts obtained from material included in glycol-metacrylate were stained with toluidin blue and submitted to the test with the Lugol reagent to detect starch (JOHANSON, 1940), mounted in synthetic resin (Permount ${ }^{\circledR}$ ) and also analyzed under polarized light to observe crystals. Cotyledon cross sections images were obtained from a light microscope (Olympus AX-70) equipped with polarization filters, U-photo photographic system, camera and microcomputer with Spot basic software.

\section{RESULTS}

The cuts stained with Sudan III showed a great quantity of lipid material in the cotyledon cells of the dry Caesalpinia peltophoroides seeds (T0) (Figure 1A).

This lipid reserve decreased gradually reduction until 20 DAS (Figure 1) a period when the first pair of seedling leaves was fully opened and the cotyledons were senescent. From then on, the quantity of lipids remaining in the cotyledon, about $100 \mathrm{mg} / \mathrm{g}$ (CORTE et al., 2006), became insignificant, and was no longer detectable in the histochemical tests. 

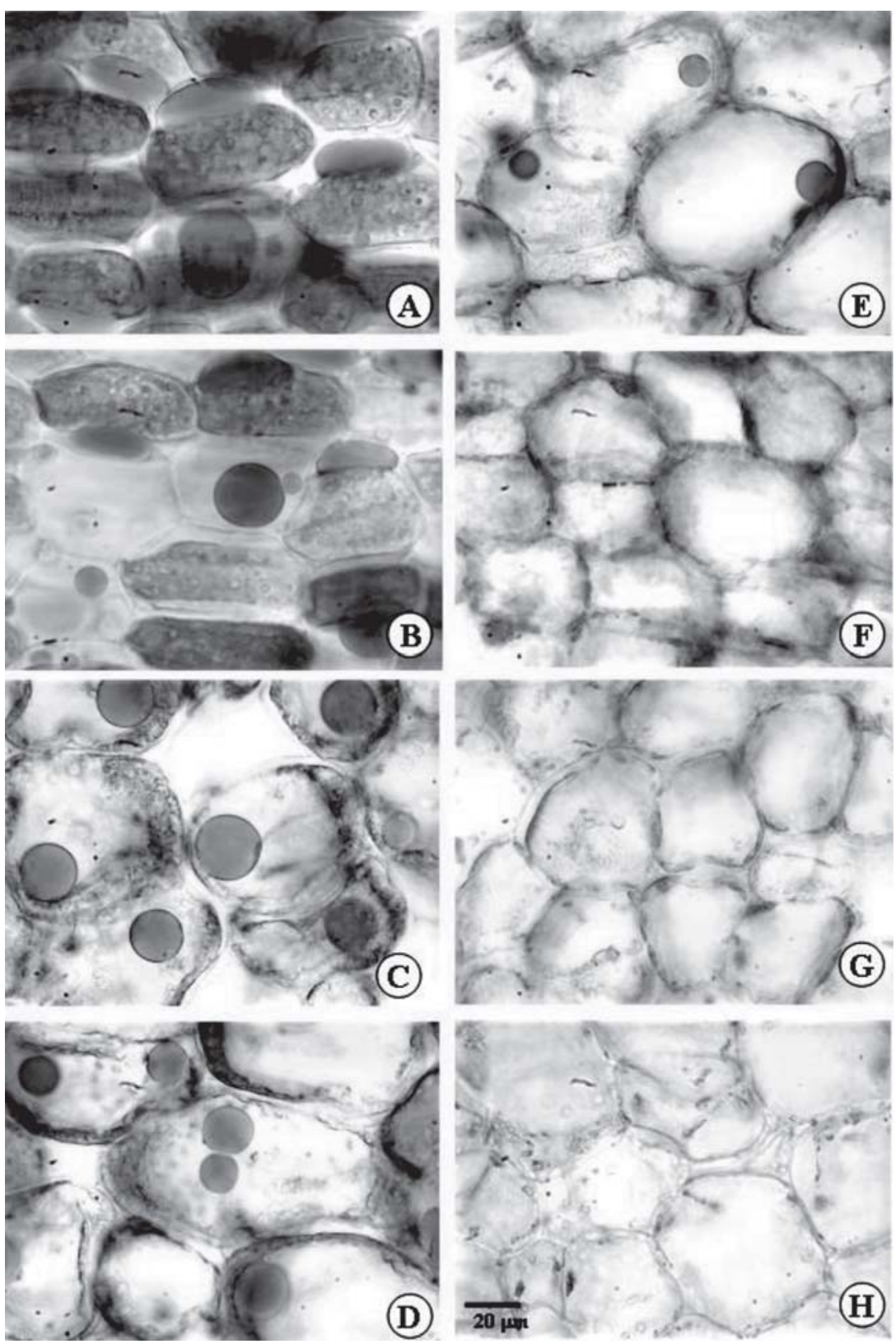

Figure 1 - Cross sections of Caesalpinia peltophoroides cotyledons submitted to the test with sudan III to identify total lipids T0 (A); T5 (B); T10 (C); T15 (D); T20 (E); T25 (F); T30 (G); T35 (H).

Figura 1 - Equações transversais de cotilédone de Caesalpinia peltophoroides submetidas a teste com Sudan III para identificação de lipídios totais. T0 (A); T5 (B); T10 (C); T15 (D); T20 (E); T25 (F); T30 (G); T35 (H).

The presence of many globular corpuscles was observed inside the cotyledon mesophyll cells, intensely stained with XP (Figure 2). These XP positive corpuscles were vacuolated structures that accumulated reserve protein in the seeds and are called protein bodies by various authors (TROMBS, 1967; DALLING and BHALLA, 1984; VIDAL and PIMENTEL, 1985; SILVA et al., 1997; MÜNTZ et al., 2001; BUCKERIDGE et al., 2004).

R. Árvore, Viçosa-MG, v.32, n.4, p.641-650, 2008 
At T0 (Figura 2A), the cotyledons of the Caesalpinia peltophoroides seeds presented many protein bodies. However, the morphology of the stained material changed significantly after the incubation period, at T5 (Figure 2B). In this period, the protein body invulcre expanded, forming internal cavities and the XP-positive material inside these corpuscles was restricted to about one third of its internal volume. Next, at T10 (Figure 2C), there was a sharp disarrangement in the globular pattern observed previously. At this stage, the protein material was fragmented by the degradation of the corpuscles and parietally displaced. From then onwards, there were only parietally vestiges of protein material that were digested and disappeared (Figures 2D to $\mathrm{H}$ ).
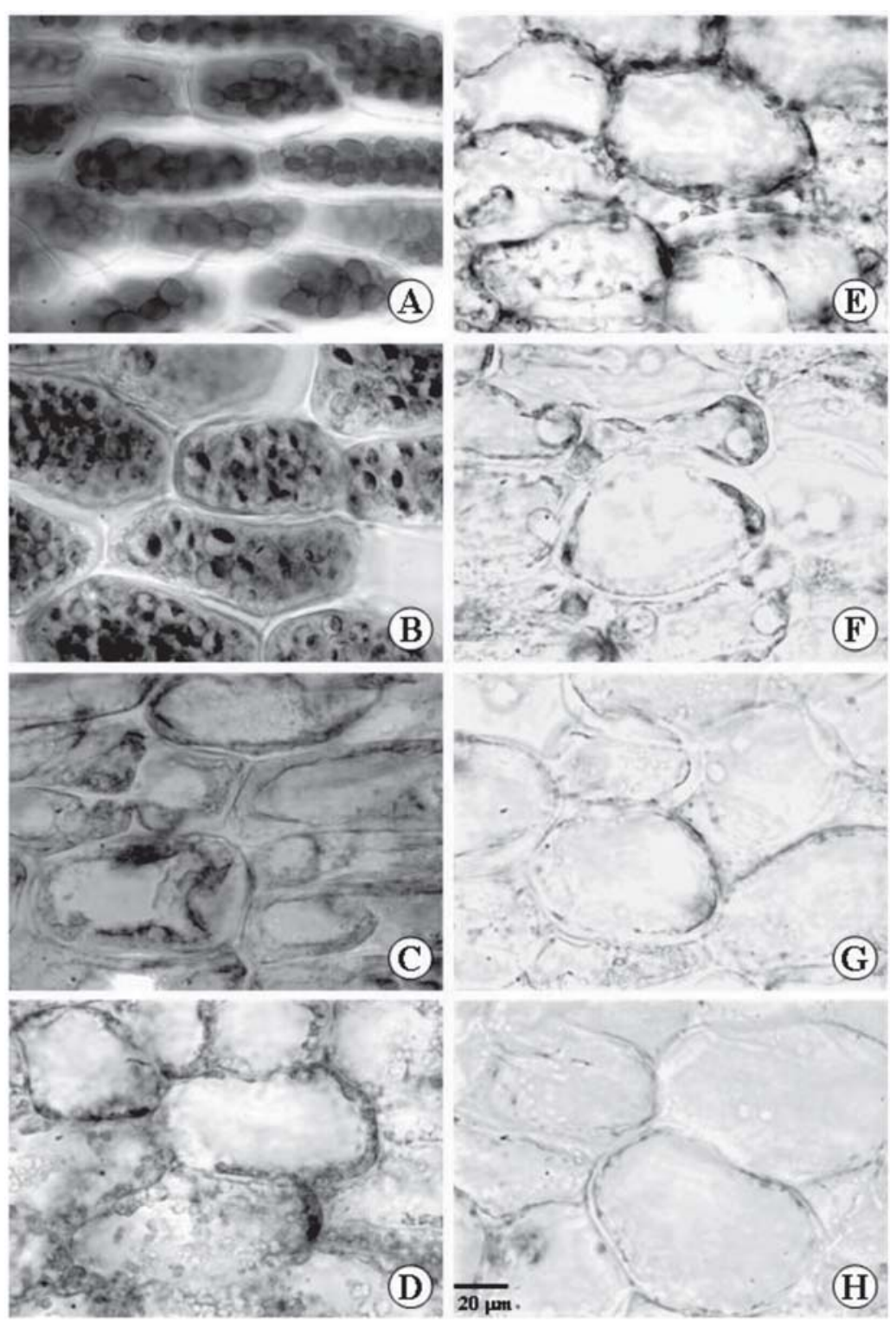

Figure 2 - Cross sections of Caesalpinia peltophoroides cotyledons submitted to the test with xylidine Ponceau to identify total proteins T0 (A); T5 (B); T10 (C); T15 (D); T20 (E); T25 (F); T30 (G); T35 (H).

Figura 2 - Seções transversais de cotilédone de Caesalpinia peltophoroides submetidas a teste com xylidine Ponceau, para identificação de proteínas totais. T0 (A); T5 (B); T10 (C); T15 (D); T20 (E); T25 (F); T30 (G); e T35 (H).

R. Árvore, Viçosa-MG, v.32, n.4, p.641-650, 2008 
Caesalpinia peltophoroides seeds presented a very small quantity of small starch grains uniformly distributed in the cotyledons in the T0 seeds (Figure 3A). In situ observations showed that the quantity of these starch grains increased between $\mathrm{T} 5$ and T15 (Figure 3B to D), a stage at which the seedlings were already established.

Starting at T10 (Figure 3C), clear parietally organization was observed of the starch grains in the cotyledons cells. This organization remained until the starch grains were completely degraded that usually occurred by T25 (Figure 3F).

A further characteristic observed in Caesalpinia peltophoroides seeds was an evident organization in the starch reserve mobilization process. These were preferentially consumed from the cotyledon abaxial surface towards the adaxial surface. It was observed that in T20 (Figure 3E) the abaxial surface no longer presented starch grains, while on the adaxial surface complete exhaustion only occurred at T30 (Figure 3G).

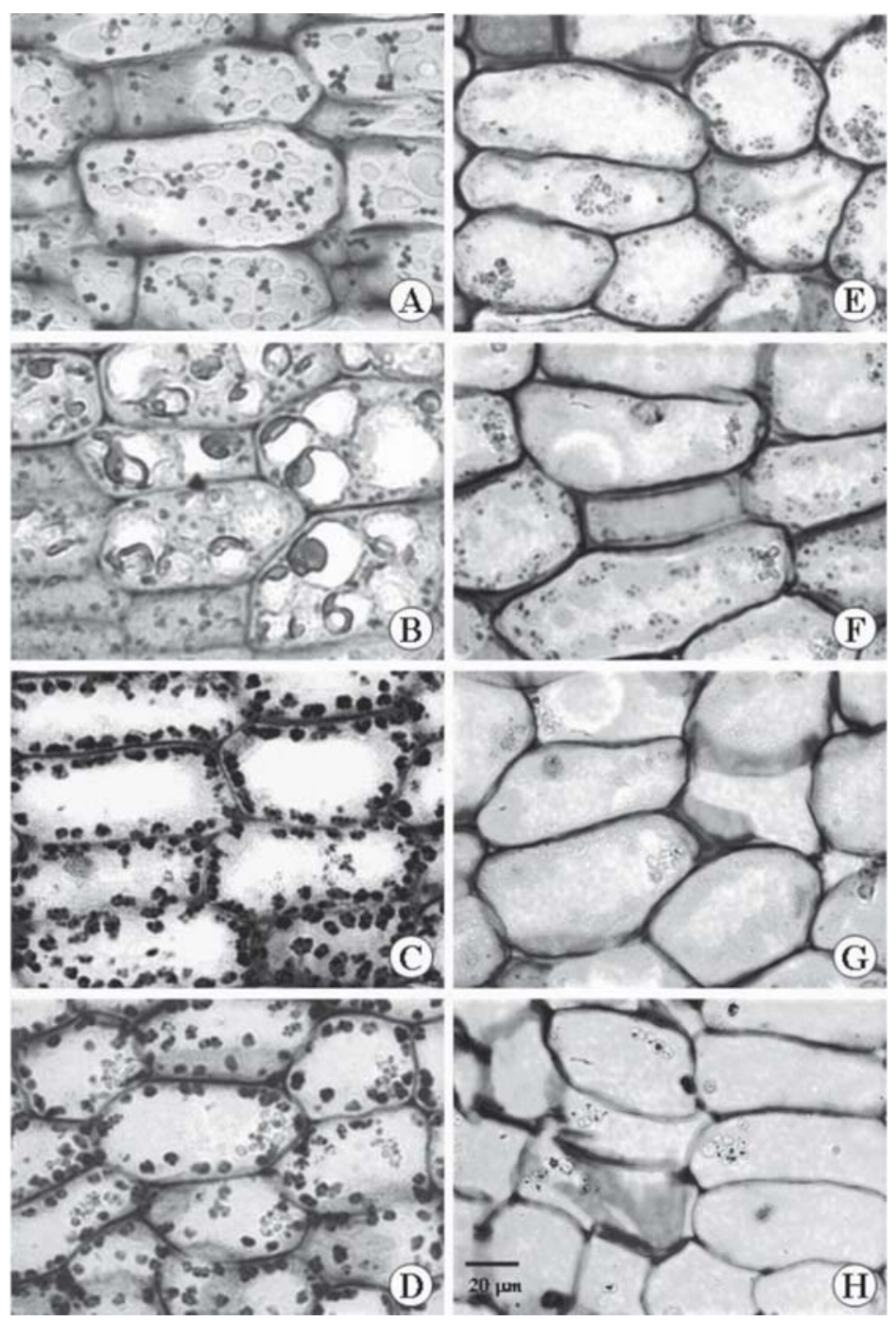

Figure 3 - Cross sections of Caesalpinia peltophoroides cotyledons submitted to the test with lugol for starch identification. T0 (A); T5 (B); T10 (C); T15 (D); T20 (E); T25 (F); T30 (G); T35 (H).

Figura 3 - Seções transversais de cotilédone de Caesalpinia peltophoroides submetidas a teste com lugol para identificação de amido. T0 (A); T5 (B); T10 (C); T15 (D); T20 (E); T25 (F); T30 (G); T35 (H). 
Small calcium oxalate druse-type crystals always appeared close to the protein bodies. These crystals are shown by their characteristic birefringence with the use of polarized light, and their chemical nature was confirmed by tests with chloridic acid and nitric acid. Calcium oxalate crystal uptake was not observed during the germination and early seedling establishment periods (Figure 4), but after T10, the druses present in each cell formed clusters that remained until the last assessment period.
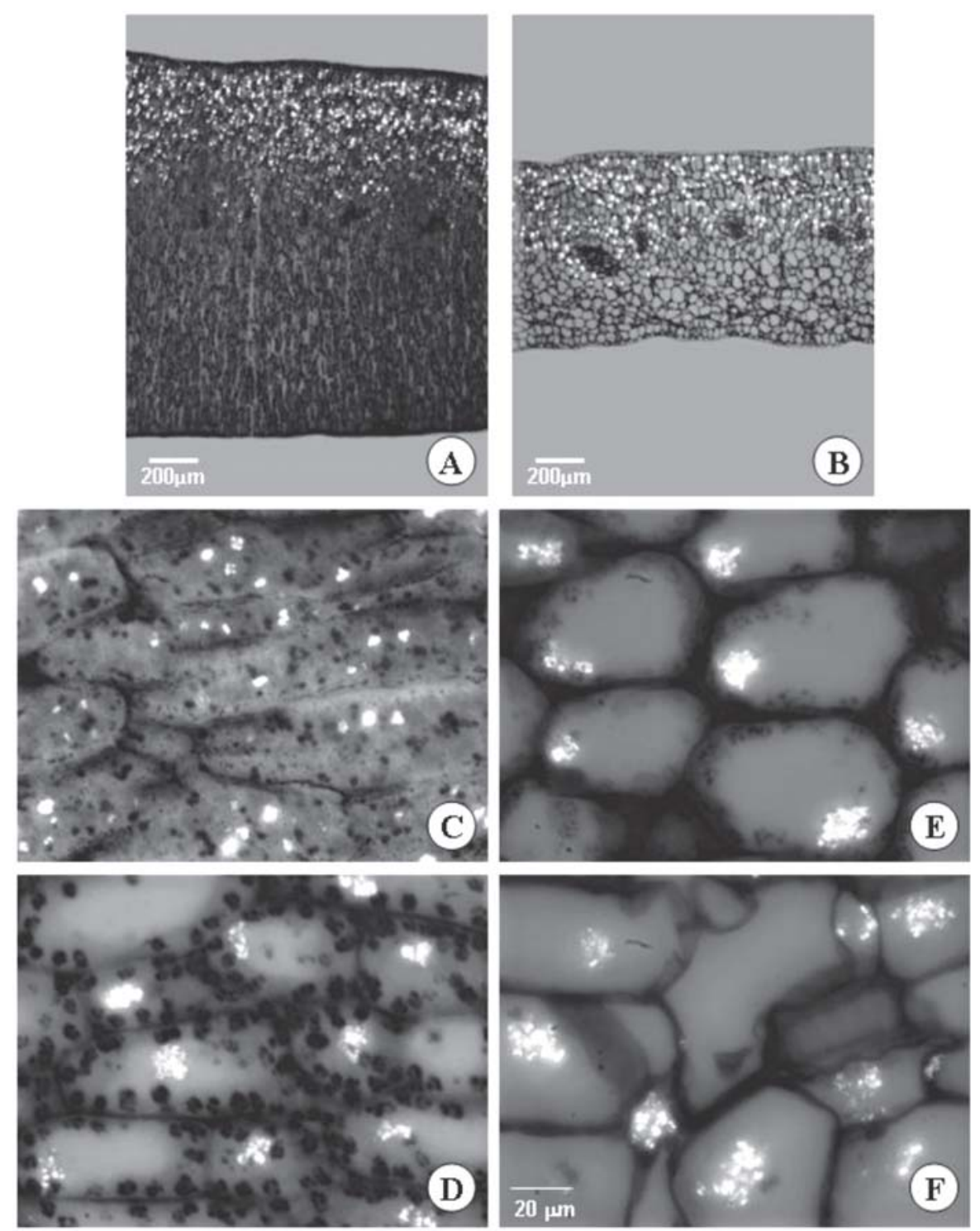

Figure 4-A and B cross section of Caesalpinia peltophoroides cotyledons. Calcium oxalate crystals located on the adaxial surface of the cotyledon at T0 (A) and T35 (B). C-F Cross sections of Caesalpinia peltophoroides cotyledons and the polarized light cross sections of Caesalpinia peltophoroides cotyledons submitted to the test with sudan III to identify total lipids T0 (A); T10 (BC); T20 (C); T30 (D).

Figura 4 - A e B: Seção transversal de cotilédone de Caesalpinia peltophoroides. Cristais de oxalato de Ca localizados na face adaxial dos cotilédones em TO (A) e T35 (B). C-F: Seções transversais de cotilédones de Caesalpinia peltophoroides sob luz polarizada.T0 (A); T10 (B); T20 (C); e T30 (D).

R. Árvore, Viçosa-MG, v.32, n.4, p.641-650, 2008

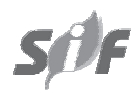




\section{DISCUSSION}

The greatest proportion of lipid material observed histochemically by the tests with sudan III in the cotyledons of dry seeds (initial time - T0) was confirmed by quantitative biochemical analysis (CORTE et al., 2006). This also occurs in other legumes, such as Dalbergia miscolobium (SILVA et al., 1997), Arachis hypogaea (TZEN, et al., 1993) and Helianthus annuus (SOROKIN, 1967) whose lipid reserves were also found in predominant quantities in the seeds.

Seeds store triacylglycerols in small cell corpuscles, delimited by phospholipid and oleasin membranes (associated proteins), called oleaginous bodies (TRELEASE and DOMAN, 1984; HUANG, 1992; TZEN, et al., 1993; FEUSSNER et al., 1995; BUCKERIDGE et al., 2004). The intense uptake of this reserve observed in Caesalpinia peltophoroides suggested the direct involvement of the lipid acting as nutrition reserve in the energetic supply for germination and postgermination growth of the seedlings. Similar results have confirmed this behavior in several species such as Phaseolus sp. (MOLLENHAUER and TOTTEN, 1971), Impatiens balsamina, I. capensis, I. ballida (NOZZOLILLO and THIE, 1984), Gossypium hirsutum, Brassica juncea, Zea mays and Sesamum indicum (TZEN et al., 1993), Cucumis sativus and Nicotiana tabacum (FEUSSNER et al., 1995), Brassica napus (TZEN et al., 1993 and BALERONI et al., 1997). Em Dalbergia miscolobium, histochemical results suggested a similar degradation pattern of the lipid and protein reserves during germination and seedling establishment (SILVA et al., 1997).

The protein content of Caesalpinia peltophoroides remained quantitatively stable in the post germination period and decreased gradually after root protrusion at T5 (BORGES et al., 2005; CORTE et al., 2006), results that confirmed those observed in the histochemical analysis.

Similar results were reported by Bagley et al. (1963) for peanut seeds, in which protein reserve degradation in the cotyledon began after germination. Similarly to Caesalpinia peltophoroides, the greatest changes in the protein reserves in peanut seeds were revealed by histochemical analysis between 4 and 9 days germination, and at 15 days, the parenchyma cells showed absence of the protein bodies or their fragments. This pattern of protein degradation has been commonly observed in several oleaginous plant seeds (BAGLEY et al., 1963; TROMBS, 1967; MANSFIELD and BRIARTY, 1996).

Euphorbia heterophylla seeds also presented protein bodies in abundance, whose fragmentation was observed only 24 hours after incubation, as they disappeared gradually up to the fourth day (SUDA and GIORGINI, 2000).

Similarly to observed in Caesalpinia peltophoroides, several authors have reported that protein hydrolysis in the reserve organs of Arachis hypogaea (TZEN et al., 1993 and BAGLEY etal., 1963), Glycine max (TROMBS, 1967), Pachyrhizus tuberosus (VIDAL and PIMENTEL, 1985), Prosopis velutina (IRVING, 1984), Pinus taeda (STONE and GIFFORD, 1997), Myrsine laetevirens (OTEGUI et al., 1998) e Erytrina velutina (OLIVEIRA et al., 1998), is followed by proteolitic product transmission to the embryonic axis.

The protein bodies were formed mainly by proteins, but showed inclusions (globoids or crystaloids), phytic acid, hydrolytic enzymes (proteases and phytases), cationic radicals and ribonucleic acid (PERNOLLET, 1978). The presence of globular inclusion characteristic in the protein bodies corresponds to phytate, the main phosphorous reserve in addition to other possible inclusions (DALLING and BHALLA, 1984). Histochemical results reported by Irving (1984) and Otegui et al. (1998) characterized the presence of inclusions of the phytin complex in protein bodies. It's suggested that phytinrich protein bodies would have a function associated with mineral reserves ( $\mathrm{P}, \mathrm{K}, \mathrm{Mg}, \mathrm{Ca}$ ). Phytin is an insoluble complex of phytic acid with catonic radical (DALLING and BHALLA,1984). As the staining by XP acted in detecting total cation radicals, it should be taken into account that this inclusion pattern, characteristic in the protein bodies, could visually overestimate the protein composition of the tissue, that could be considered in this case, when comparison of the histochemical analysis with the quantitative results showed only $7.7 \%$ protein in the seeds (CORTE et al., 2006).

Carbohydrates are also transferred to the cotyledons for growth of the embryonic axis, as already reported for Canavalia ensiformis and $C$. gladiata (CORTELAZZO, 1992), Euphorbia heterophylla (SUDA and GIORGINI, 2000) and Senna macranthera (BORGES et al., 2002).

R. Árvore, Viçosa-MG, v.32, n.4, p.641-650, 2008 
Because of the tiny size of the starch grains in this material, it was chosen to use material included in glycol-metacylate because of the greater integrity conferred to the structures by this inclusion medium, that also permitted thinner cuts with better image quality for the light microscope.

The small proportion and the tiny sizes observed in the starch grains in Caesalpinia peltophoroides seeds were similar to those observed in other legumes (BAGLEY, et al., 1963; IRVING, 1984; HEGNAUER and GPAYER-BARKMEIJER, 1993; SILVA et al., 1998). However, this small proportion increased visually between the 5th and 15th days, the period that coincided with the intense degradation phase in the lipid reserves (Figure 2B-D) that may have contributed to this temporary increase in starch reserves, because the biochemical path of lipid degradation, that involves oxidation and the glyoxylate cycle, lead to saccharine synthesis, via gluconeogenesis, and this, when present in high concentrations in the cytosol, can be temporarily stored as starch (BUCKERIDGE et al., 2004). The same result was observed for seeds of Dalbergia miscolobium (SILVA et al., 1998) and Arabidopsis thaliana (MANSFIELD and BRIARTY, 1996).

This temporary increase was followed, as expected, by a continuous degradation that culminated with the visual disappearance of the starch reserves. Similar results were reported by Cortelazzo (1992), in seeds of Canavalia ensiformis and C. gladiata, where the quantity and size of the starch grains decreased after incubation, with almost total exhaustion around 20 and 30 days, respectively. The decrease in the starch content may be related to its degradation for glucose production as energy source for the various metabolic reactions that take place during seedling germination and early growth and is also a source of glucose for cellulose biosynthesis (SILVA et al., 1998).

Calcium accumulation in Caesalpinia peltophoroides cotyledons, in the form of calcium oxalate crystals, could not be associated to the reserve function, because they were not consumed. The function of the calcium oxalate crystals is still a cause of controversy, because recent studies have shown that these cystals can be dissolved under calcium deficiency conditions (VOLK et al., 2002). However, the low mobility of calcium in the phloem should be considered, that reduces the possibility of transporting this ion to distant locations (MARSCHNER, 1986).

R. Árvore, Viçosa-MG, v.32, n.4, p.641-650, 2008
The lipids, present in a great quantity in the cotyledon, decreased in the period studied. There was an increase in the amount of starch on the 10th DAS, and it was totally consumed by 30 DAS. The protein material was intensely consumed after 10 DAS, and disappeared at 25 DAS. The calcium oxalate druses were not consumed, and its function as reserve was no proved.

\section{ACKNOWLEDGEMENTS}

V. B. Corte is grateful to CNPq (Conselho Nacional de Desenvolvimento Científico e Tecnológico) for the finacial support.

\section{REFERENCES}

BAGLEY BW, CHERRY JH, ROLLINS ML, ALTSCHUL AM. A study of protein during germination of peanut (Arachis hypogaea) seed. Amer. Journal of Botany. 50(6), 523-532, 1963.

BALERONI CRS, FERRARESE MLL, COSTA SC, SOUZA NE, FERRARESE-FILHO O. Isocitrate lyase activity and mobilization of lipids and carbohydrates in cotyledons of canola. Rev. Bras. Fisol. Veg. v.9, n.3, 189-192, 1997.

BORGES EEL, BORGES RCG, SOARES CPB, PEREZ SCJGA. Crescimento e mobilização de carboidrato em embrião de sementes de fedegoso (Senna macranthera Irwin et Barneby) durante a germinação. Revista Cerne. vol.8, n.1, 69-76, 2002.

BORGES EEL, REZENDE ST, GONÇALVES RCB, PEREZ SCJGA. Caracterização de Alfagalactosidase e sua relação coma germinação de sementes de Caesalpinia peltophoroides (Leguminosae -

Caesalpinoideae). Revista Árvore, v.29, n.4, 525-533, 2005.

BORGES EEL, RENA AB. Germinação de sementes. In: AGUIAR IB, PIÑA-RODRIGUES FCM, FIGLIOLIA MB. Sementes

florestais tropicais. Brasília: ABRATES, 1993, 350 p. 
BUCKERIDGE MS, AIDAR MPM, SANTOS HP, TINÉ MAS. Acúmulo de Reservas. In: FERREIRA AG, BORGHETTI F. Germinação: do básico ao aplicado. Porto Alegre: Artmed, 2004, 323.

CHAMBERLAIN CJ Methods in plant histology. $5^{\mathrm{a}}$ ed. Chicago, The University of Chicago Press, 1932, 416 p.

CORTE VB, BORGES EEL, PONTES CA, LEITE ITA, VENTRELLA MC, MATHIAS AA Mobilização de reservas durante a germinação das sementes e crescimento das plântulas de Caesalpinia peltophoroides Benth. (Leguminosae-Caesalpinoideae). Revista Árvore, v.30, n.6, 941-949, 2006.

CORTELAZZO AL Detecção e quantificação do amido em cotilédones de Canavalia ensiformis e C. gladiata durante o desenvolvimento inicial da planta. Revista Brasileira de Botânica, v.15, n.2, 157-162, 1992.

CORTELAZZO AL, VIDAL BC Soybean seed proteins: Detection in situ and mobilization during germination. Rev. Bras. Bot. vol. 14, 27-33, 1991.

DALLING MJ, BHALLA PL Mobilization of nitrogen and phosphorus from endosperm. In: Murray DR Seed Physiology: germination and reserve mobilization. v.2, Australia: Academic Press, 1984.

DAVIES HV, SLACK PT The control of food mobilization in seeds of dicotyledonous plants. New Phytol. v.88, 41-51, 1981.

FEUSSNER I, WASTERNACK C, KINDL H, KÜHN H Lipoxygenase-catalysed oxygenation of storadge lipids is implicated in lipid mobilization during germination. Plant Biology, v.2, 11849-11853, 1995.

HEGNAUER R, GPAYER-BARKMEIJER RJ

Relevance of seed polysaccharides and flavonoids for the classification of the leguminosae: A chemotaxonomic approach. Phytochemistry. Vol.34, n.1, 316, 1993.
HUANG AHC Oil bodies and oleosins in seeds. Annu Rev Plant Physiol Plant Mol Biol v.43, 177-200, 1992.

IRVING DW Seed structure and histochemistry of Prosopis velutina (Leguminosae).

Botanical Gazete, 145(3), 340-345, 1984.

JOHANSEN DA Plant microtechnique. New York: McGraw-Hill Book Co. Inc., 1940, 423p.

LORENZI H Árvores brasileiras: Manual e cultivo de plantas arbóreas nativas do Brasil. Nova Odessa: Ed. Plantarum, 2002, p.352.

MANSFIELD SG, BRIARTY LG The dynamics of seedling and cotyledon cell development in Arabidopsis thaliana during reserve mobilization. Int. Journal Plant Science, v.157, n.3, 280-295, 1996.

MARSCHNER H Mineral nutrition of higher plants. New York: Academic Press, 1986.

MOLLENHAUER HH, TOTTEN C Studies on seeds. I. Origin and degradation of vesicles in pea and bean cotyledons. The Journal of Cell Biology, v.48, 395-405, 1971.

MÜNTZ K, BELOZERSKY MA, DUNAEVSKY YE, SCHLERETH A, TIEDEMANN J Stored proteinases and the initiation of storage protein mobilization in seeds during germination and seedling growth. Journal of

Experimental Botany, v.52, n.362, 17411752, 2001.

NOZZOLILLO C, THIE I A comparative study of mobilization of lipid and carbohydrate reserves during germination of seeds of three species of Impatiens (Balsaminaceae): I. balsamina L., I. capensis Meerb. and I. ballida Nutt. Torrey Botanical Club, vol. 111, n.2, 200-208, 1984.

OLIVEIRA JTA, MORAES SMD, CAVADA BS, MOREIRA RA, VASONCELOS IM Protein and lecitin mobilization during Erythrina velutina forma Aurantiaca seed germination and seedling growth in the dark. Revista Brasileira de Fisiologia Vegetal, vol.10, n.1, 25-30, 1998.

R. Árvore, Viçosa-MG, v.32, n.4, p.641-650, 2008 
OTEGUI M, LIMA C, MALDONADO S, LEDERKREMER RM Histological and chemical characterization of Myrsine laetevirens seed. International Journal Plant Science. 159 (5), 762-772, 1998.

PERNOLLET JC Protein bodies of seeds: ultrastructure biochemistry, biosynthesis and degradation. Phytochemistry, v.17, 14731480, 1978.

PRITCHARD SL, CHARLTON WL, BAKER A, GRAHAM LA Germination and storage reserve mobilization are regulated independently in Arabidopsis. The Plant Journal. Vol. 31, n.5, 639-647, 2002.

SILVA TRG, CORTELAZZO AL, DIETRICH SMC Cytological aspects of storage mobilization in seeds of Dalbergia miscolobium during germination and plantlet growth. Ciência e Cultura. Journal of the Brasilian Association for the Advancement of Science. Vol.49, n.3, 219-222, 1997.

SILVA TRG, CORTELAZZO AL, DIETRICH SMC Variations in storage compounds during germination and early plantlet growth of Dalbergia miscolobium. Revista Bras.

Fisiologia Vegetal, v.10, n.2, 119-124, 1998.

SOROKIN HP The spherosomes and the reserve fat in plant cells. Amer. Journal Botany, v.54, n.8, 1008-1016, 1967.
STONE SL, GIFFORD DJ Structural and biochemical changes in loblolly pine (Pinus taeda L.) seeds during germination and early-seedling growth. I. Storage protein reserves. International Journal Plant Science, v.158, n.6, 727-737, 1997.

SUDA CNK, GIORGINI JF Seed reserve composition and mobilization during germination and initial seedling development of Euphorbia heterophylla. Rev. Bras. Fisiologia Vegetal. Vol.12, n.3, 226-245, 2000.

TRELEASE RN, DOMAN DC. Mobilization of oil and wax reserves. In: Murray (ed.), D.R. Seed physiology: germination and reserve mobilization. Academic Press, v.2, 1984, 201-245.

TROMBS MP Protein bodies of the soybean. Plant Physiology, n.42, 797-813, 1967.

TZEN JTC, CAO Y, LAURENT P, RATNAYAKE C, HUANG AHC Lipids, proteins, and structure of seed oil bodies from diverse species. Plant Physiol. v.101, 267-276, 1993.

VIDAL BC, PIMENTEL ER Caracterização bioquímica, topoquímica e estrutural dos corpos protéicos do feijão macuco ou jacatupé (Pachyrhizus tuberosus (Lam.) Spreng). Revista Brasileira de Botânica, n.8, 223-229, 1985.

VOLK GM, LYNCH-HOLM VJ, KOSTMAN TA, GOSS LG The role of druse and raphide calcium oxalate crystals in tissue calcium regulation in Pistia stratiotes leaves. Plant Biology, vol.4, n.1, 34-45, 2002. 